Archive for

Organic Chemistry

Arkivoc 2017, iii, 326-334

\title{
Highly efficient regioselective synthesis of organotellurium compounds based on the reactions of tellurium tetrachloride with 1-alkenes
}

\author{
Vladimir A. Potapov,* Maria V. Musalova, Svetlana I. Udalova, Maxim V. Musalov, \\ Alfiya G. Khabibulina, and Svetlana V. Amosova*
}

A. E. Favorsky Irkutsk Institute of Chemistry, Siberian Division of the Russian Academy of Sciences, 1 Favorsky Str., Irkutsk 664033, Russian Federation

Email: va potapov@irioch.irk.ru, amosova@irioch.irk.ru

Dedicated to Prof. Oleg A. Rakitin on the occasion of his 65th birthday

Received 07-21-2017

Accepted 08-14-2017

Published on line $08-31-2017$

\begin{abstract}
Efficient regioselective syntheses of trichloro-(2-chloroalkyl)- $\lambda^{4}$-tellanes, trichloro-(2-alkoxyalkyl)-- $\lambda^{4}$-tellanes, bis-(2-alkoxyalkyl)ditellanes and dichlorobis-(2-chloroalkyl)- $\lambda^{4}$-tellanes in quantitative yields were developed based on tellurium tetrachloride and 1-alkenes (1-hexene and 1-heptene). Favorable conditions for selective preparation of both mono- and bis-adducts of tellurium tetrachloride with 1-alkenes were established. Methoxytelluration was accomplished by the reaction of tellurium tetrachloride with 1-alkenes in $\mathrm{CH}_{2} \mathrm{Cl}_{2} / \mathrm{MeOH}$ at room temperature. Ethoxytelluration was carried out in $\mathrm{CH}_{2} \mathrm{Cl}_{2} / \mathrm{EtOH}$ at reflux. Trichloro-(2alkoxyalkyl)- $\lambda^{4}$-tellanes were also obtained by nucleophilic substitution of chlorine atom in trichloro-(2chloroalkyl)- $\lambda^{4}$-tellanes with alcohols under unusually mild conditions.
\end{abstract}

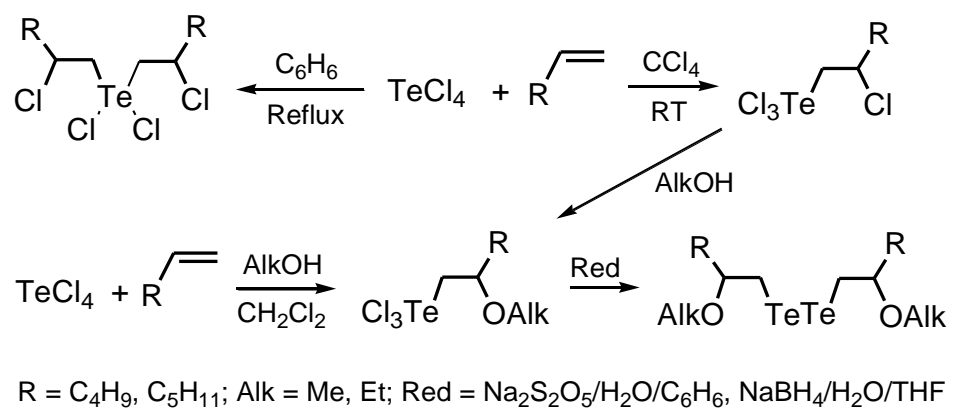

Keywords: Alkenes, tellurium tetrachloride, alkoxytelluration, regioselective addition, tellanes 


\section{Introduction}

Organotellurium compounds are used in modern organic synthesis as intermediates and synthons. ${ }^{1,2}$ Tellurium was considered to be a poison for many years; however, non-toxic substances with high biological activity have been recently found among tellurium compounds including ones with anti-viral, anti-epileptic, antimalarial and glutathione peroxidase-like action. ${ }^{3-9}$ Several discoveries have been recently made which renewed interest in organotellurium chemistry. ${ }^{3-9}$ Bioincorporation of telluromethionine provides a new approach to add heavy atoms to selected sites in proteins. ${ }^{7}$ Ammonium trichloro-dioxoethylene-O,O'-tellurate, also known as AS-101 (Figure 1), which can be prepared from tellurium tetrachloride, shows high immune modulating activity. ${ }^{3-7}$ It is known that AS-101 is potentially useful in the treatment of clinical immunosuppression conditions including cancer and AIDS..$^{3-7} \mathrm{~A}$ number of addition products of tellurium tetrachloride to unsaturated compounds exhibit high antioxidant, anti-leishmanial (RT-01), anti-epileptic (RF-07) activities, as well as the property of potent inactivation of recombinant human cathepsin B (RT-04) (Figure 1). ${ }^{3-7}$

The distinguishing property of tellurium reagents to react with high regio- and stereo-selectivity finds increasing application in organic synthesis. ${ }^{1,2}$ Adducts of tellurium tetrachloride with acetylenes were recognized as important precursors and synthons for organic synthesis and applied in many approaches for the preparation of various functionalized alkenes in a highly regio- and stereo-selective manner. ${ }^{1,2}$ Data on the addition of tellurium tetrachloride to alkenes are scarce in the literature and mainly reported in relatively old works. ${ }^{10-15}$

We are making a systematic study of the reactions of tellurium tetrahalides with unsaturated compounds. ${ }^{16-25}$ Recently we have found that methoxytelluration can be accomplished by the reaction of tellurium tetrabromide with 1-hexene in methanol. ${ }^{17}$ The reaction proceeded with high regioselectivity to afford Markovnikov's products, tribromo-(2-methoxyhexyl)-- $\lambda^{4}$-tellane. This result showed for the first time that methanol can be used as solvent in reactions of tellurium tetrabromide without methanolysis of the $\mathrm{Te}-\mathrm{Br}$ bond and demonstrated an example of an efficient methoxytelluration reaction. Similar methoxytelluration reactions were accomplished with styrene and 1-octene. ${ }^{18,19}$ Tellurium tetrachloride cannot be used under similar conditions due to methanolysis of the $\mathrm{Te}-\mathrm{Cl}$ bond. However, we found that methoxytelluration reaction of tellurium tetrachloride can be carried out in a mixture of chloroform and methanol. ${ }^{19,20}$

The present paper is devoted to regioselective synthesis of organotellurium compounds based on chlorotelluration and alkoxytelluration reactions of tellurium tetrachloride with 1-hexene and 1-heptene. Examples of nucleophilic substitution of chlorine atom in trichloro-(2-chloroalkyl)- $\lambda^{4}$-tellanes with alcohols under unusually mild conditions are discussed. Highly efficient syntheses of 2-haloalkyl, 2-methoxyalkyl and 2ethoxyalkyl tellanes and ditellanes in quantitative yields have been accomplished based on these reactions. Prior to our studies, the addition products of tellurium tetrachloride to 1-hexene or 1-heptene were not described in the literature.

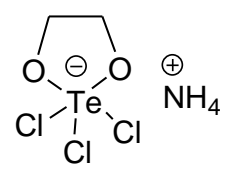

AS-101

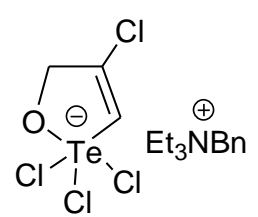

RT-01

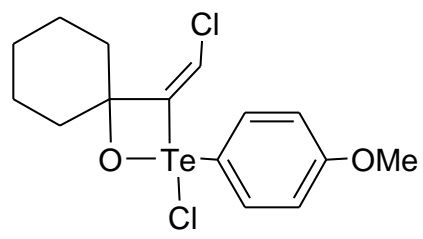

RF-07

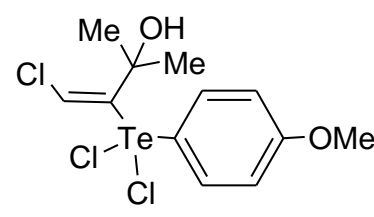

RT-04

Figure 1. Biologically active compounds based on tellurium tetrachloride. 
The reactions of tellurium tetrachloride with 1-hexene (1) and 1-heptene (2) have been systematically studied. We have found that best solvent for chemo- and regio-selective synthesis of monoadducts by addition of tellurium tetrachloride to alkenes $\mathbf{1}$ and $\mathbf{2}$ is carbon tetrachloride. The reactions of tellurium tetrachloride with 1-alkenes $\mathbf{1}$ and $\mathbf{2}$ proceed in carbon tetrachloride at room temperature with an equimolar ratio of reagents affording trichloro-(2-chloroalkyl)- $\lambda^{4}$-tellanes $\mathbf{3}$ and $\mathbf{4}$ in quantitative yield (Scheme 1).

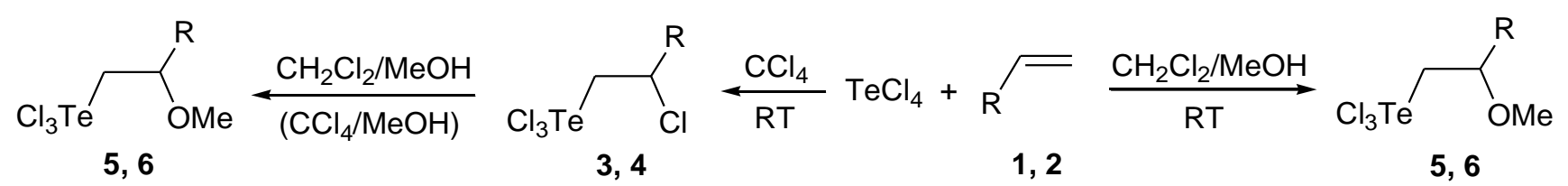

$$
\mathrm{R}=\mathrm{C}_{4} \mathrm{H}_{9}(\mathbf{1}, \mathbf{3}, \mathbf{5}), \mathrm{C}_{5} \mathrm{H}_{11}(\mathbf{2}, \mathbf{4}, \mathbf{6})
$$

Scheme 1. The addition and methoxytelluration reactions of tellurium tetrachloride with 1-alkenes.

The addition can also be accomplished in dichloromethane or chloroform at room temperature. However, the highest purity of monoadducts $\mathbf{3}$ and $\mathbf{4}$ was observed when the reactions were carried out in carbon tetrachloride.

The system $\mathrm{CH}_{2} \mathrm{Cl}_{2}$-methanol (5-3: 1 , equimolar ratio of reagents) is found to be favorable for accomplishing the methoxytelluration reaction of tellurium tetrachloride with $\mathbf{1}$-alkenes $\mathbf{1}$ and $\mathbf{2}$. The methoxytelluration reaction in the system $\mathrm{CH}_{2} \mathrm{Cl}_{2}$-methanol proceeds at room temperature affording trichloro(2-methoxyalkyl)- $\lambda^{4}$-tellanes $\mathbf{5}$ and $\mathbf{6}$ in quantitative yield and with higher purity than in the chloroformmethanol mixture. ${ }^{19,20}$

We found that tellanes $\mathbf{5}$ and $\mathbf{6}$ can be also obtained in quantitative yield by nucleophilic substitution of chlorine atom in tellanes $\mathbf{3}$ and $\mathbf{4}$ with alcohols under unusually mild conditions. The reaction proceeded smoothly at room temperature in the systems $\mathrm{CH}_{2} \mathrm{Cl}_{2}$-methanol or chloroform-methanol giving tellanes $\mathbf{5}$ and 6 in quantitative yields. The nucleophilic substitution reaction proceeded more slowly in methanol or in carbon tetrachloride-methanol mixture then in the system $\mathrm{CH}_{2} \mathrm{Cl}_{2}$-methanol. In order to accomplish nucleophilic substitution reaction it is sufficient to add methanol to a solution of tellanes $\mathbf{3}$ or $\mathbf{4}$ in dichloromethane or chloroform and allowed to stand overnight. Methanol can be added to a solution of tellanes $\mathbf{3}$ or $\mathbf{4}$ in carbon tetrachloride after accomplishing the addition reaction; however, warming the reaction mixture at $50-60^{\circ} \mathrm{C}$ is necessary in order to complete nucleophilic substitution reaction and to obtain tellanes $\mathbf{5}$ and $\mathbf{6}$ in quantitative yield. This case can be regarded as one-pot synthesis of tellanes $\mathbf{5}$ and $\mathbf{6}$ by addition of tellurium tetrachloride to alkenes $\mathbf{1}$ and $\mathbf{2}$ followed by nucleophilic substitution of in situ formed tellanes $\mathbf{3}$ or $\mathbf{4}$. It is noteworthy that carrying out the reaction under these conditions avoids the methanolysis of the Te-Cl bond.

The ease of the reaction of nucleophilic substitution of chlorine is apparently due to the high electronwithdrawing effect of the trichlorotellanyl group. This opens up new possibilities for the functionalization of organotellurium compounds obtained by the addition of tellurium tetrachloride to alkenes. Noteworthy, under similar conditions the chlorine atoms in the bis-adducts dichlorobis-(2-chloroalkyl)- $\lambda^{4}$-tellanes $\mathbf{7}$ and $\mathbf{8}$ were not displaced by methanol. This may indicate that electron-withdrawing effect of the trichlorotellanyl group is considerably higher than that of the dichloro(organyl)tellanyl group. 
It was found that the optimal conditions for preparation of bis-adducts $\mathbf{7}$ and $\mathbf{8}$ are reflux of tellurium tetrachloride with a 2.5-3-fold excess of alkenes in benzene (Scheme 2). The reaction proceeded chemo- and regioselectively to afford compounds $\mathbf{7}$ and $\mathbf{8}$ in quantitative yield.

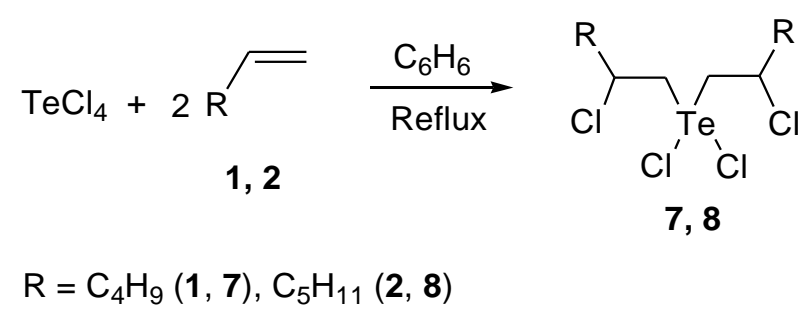

Scheme 2. The synthesis of dichlorobis-(2-chloroalkyl)- $\lambda^{4}$-tellanes $\mathbf{7}$ and $\mathbf{8}$.

The ethoxytelluration reaction of tellurium tetrachloride with 1-alkenes $\mathbf{1}$ and $\mathbf{2}$ can be accomplished in the systems $\mathrm{CH}_{2} \mathrm{Cl}_{2} / \mathrm{EtOH}, \mathrm{CHCl}_{3} / \mathrm{EtOH}$ or $\mathrm{CCl}_{4} / \mathrm{EtOH}(6-3: 1)$. However, the reaction was slow at room temperature and usually required heating under reflux for $6 \mathrm{~h}$ in order to complete the ethoxytelluration and to obtain trichloro-(2-ethoxyalkyl)- $\lambda^{4}$-tellanes 9 and 10 in quantitative yields (Scheme 3). The purity of the products varied from 94 to $96 \%$ (NMR data). The ethoxytelluration products with higher purity (>96\%) were obtained by one-pot procedure by addition of tellurium tetrachloride to alkenes $\mathbf{1}$ and $\mathbf{2}$ followed by nucleophilic substitution of formed in situ tellanes $\mathbf{3}$ or $\mathbf{4}$. Similarly to the ethoxytelluration reaction, the onepot synthesis of tellanes 9 and 10 can be realized in the systems $\mathrm{CH}_{2} \mathrm{Cl}_{2} / \mathrm{EtOH}, \mathrm{CHCl}_{3} / \mathrm{EtOH}$ or $\mathrm{CCl}_{4} / \mathrm{EtOH}$ and requires heating in order to complete the process (Scheme 3). For example, heating at reflux $\left(40{ }^{\circ} \mathrm{C}\right.$ ) for $6 \mathrm{~h}$ in the system $\mathrm{CH}_{2} \mathrm{Cl}_{2} / \mathrm{EtOH}$ is sufficient for completion of the reaction. It is possible to add ethanol to the reaction mixture after accomplishing the addition of tellurium tetrachloride to 1 -alkenes $\mathbf{1}$ and $\mathbf{2}$ in carbon tetrachloride and after $6 \mathrm{~h}$ reflux tellanes 9 and 10 can be isolated in quantitative yield.

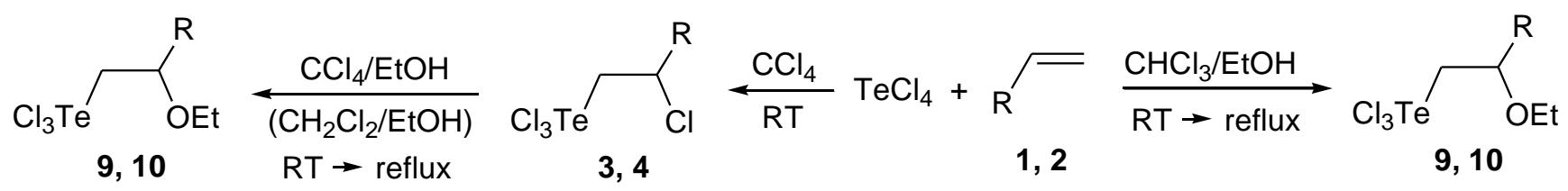

$$
R=\mathrm{C}_{4} \mathrm{H}_{9}(1,3,9), \mathrm{C}_{5} \mathrm{H}_{11}(2,4,10)
$$

Scheme 3. Synthesis of trichloro-(2-ethoxyalkyl)- $\lambda^{4}$-tellanes $\mathbf{9}$ and $\mathbf{1 0}$.

Reduction of compounds 5, 6, 9 and $\mathbf{1 0}$ with sodium metabisulfite in a two-phase system benzene-water at room temperature leads to bis-(2-alkoxyalkyl)ditellanes $\mathbf{1 1 - 1 4}$ in 72-80\% yields (Scheme 4). It was found that the system $\mathrm{NaBH}_{4}$ /water/THF is more efficient and selective for the preparation of ditellanes $11-14 .{ }^{26}$ When this system was applied for the reduction of compounds $5,6,9$ and 10 at $-20{ }^{\circ} \mathrm{C}$ (molar ratio of tellane- $\mathrm{NaBH}_{4}$ 2 : 3), the target ditellanes $\mathbf{1 1 - 1 4}$ were obtained in near quantitative yields (95-98\%) (Scheme 4). 


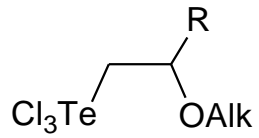

$5,6,9,10$

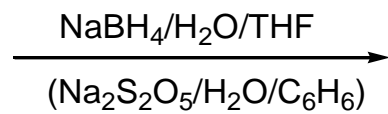

$\left(\mathrm{Na}_{2} \mathrm{~S}_{2} \mathrm{O}_{5} / \mathrm{H}_{2} \mathrm{O} / \mathrm{C}_{6} \mathrm{H}_{6}\right)$

$\mathrm{R}=\mathrm{C}_{4} \mathrm{H}_{9}(5,9,11,13), \mathrm{C}_{5} \mathrm{H}_{11}(6,10,12,14)$

Alk $=$ Me $(5,6,11,12)$, Et $(9,10,13,14)$

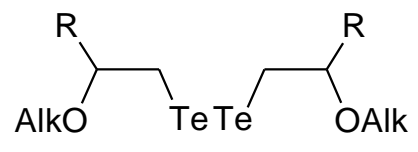

11-14

Scheme 4. Synthesis of bis-(2-alkoxyalkyl)ditellanes 11-14 by reduction of compounds 5, 6, 9, 10.

Organic ditellanes are important reagents for preparation of many other tellurium organic derivatives. Halogenation of diorganyl ditellanes provides widely used electrophilic reagents of the type RTeX and RTeX and the reduction of diorganyl ditellanes leads to corresponding organyltellurolate anions which are applied as strong nucleophilic reagents. ${ }^{1,2}$

Attempts to carry out the reduction of compounds 3, 4, 7 and $\mathbf{8}$ with sodium metabisulfite in a two-phase system benzene-water at room temperature as well as in the system sodium borohydride/water/THF at $-20{ }^{\circ} \mathrm{C}$ led to mixtures of products and tellurium precipitation.

The structural assignment of compounds 3-14 was made by ${ }^{1} \mathrm{H}$ and ${ }^{13} \mathrm{C}$ NMR and confirmed by elemental analysis. The spin-spin coupling constants of ${ }^{125} \mathrm{Te}$ with the carbon atom of the $\mathrm{CH}_{2}$ group were measured for some synthesized compounds. The obtained values (138 and $115 \mathrm{~Hz}$ for compounds 4 and 6, respectively) correspond to the direct coupling constants $\left({ }^{1} J_{\mathrm{Te}-\mathrm{c}}\right)$. This indicates the addition of tellurium to occur at the terminal carbon atom of 1-alkenes according to Markovnikov rule. Bis-adducts 7 and 8 and ditellanes 11-14 have two chiral carbon atoms and represent equimolar mixtures of two diastereomers $(d, l$ - and meso-forms, $S R / R S$ and $R R / S S$ ). The diastereomers of bis-adducts 7 and $\mathbf{8}$ exhibit different signals in NMR spectra (in some cases the signals of two diastereomers coincided). The difference in chemical shift values of two diastereomers was observed especially for carbon atoms of the $\mathrm{ClCH}-\mathrm{CH}_{2} \mathrm{Te}$ group. For example, the $\mathrm{CH}_{2} \mathrm{Te}$ group manifests at 55.1 and 55.4 ppm and the $\mathrm{ClCH}$ fragment appears at 58.0 and $58.1 \mathrm{ppm}$ in the ${ }^{13} \mathrm{C}$ NMR spectrum of compound 7. No significant difference in chemical shift was observed for diastereomers of ditellanes 11-14.

\section{Conclusions}

Highly efficient syntheses of 2-chloroalkyl, 2-methoxyalkyl and 2-ethoxyalkyl tellanes and ditellanes in quantitative yield have been developed based on reactions of tellurium tetrachloride with 1-alkenes. The high chemo- and regio-selectivity of the reactions is worth noting: formation of the addition products exclusively according to the Markovnikov rule was observed.

Interesting results were obtained on studying the nucleophilic substitution reaction of chlorine by a methoxy group, which proceeded under unusually mild conditions at room temperature in the systems $\mathrm{CH}_{2} \mathrm{Cl}_{2}$ methanol or chloroform-methanol, giving tellanes $\mathbf{5}$ and $\mathbf{6}$ in quantitative yields. The ease of the nucleophilic substitution of chlorine disclosed new possibilities for the functionalization of organotellurium compounds obtained by the addition of tellurium tetrachloride to alkenes.

The products 3-14 are valuable starting material for preparation of novel organotellurium compounds and intermediates for organic synthesis. 


\section{Experimental Section}

General. NMR spectra were recorded on a Bruker DPX-400 instrument. ${ }^{1} \mathrm{H}$ NMR spectra were acquired at operating frequencies $400.13 \mathrm{MHz}$ and chemical shifts were recorded relative to $\mathrm{SiMe}_{4}(\delta 0.00)$ or solvent resonance $\left(\mathrm{CDCl}_{3} \delta\right.$ 7.26). ${ }^{13} \mathrm{C} \mathrm{NMR}$ spectra were acquired at $100.61 \mathrm{~Hz}$ and chemical shifts were recorded relative to solvent resonance $\left(\mathrm{CDCl}_{3} \delta 77.23\right.$ or $\left.\mathrm{CCl}_{4} \delta 96.70\right)$.

Elemental analysis of carbon and hydrogen was performed on the THERMO Flash EA1112 analyzer. Analytical determination of chlorine and tellurium was made by known combustion methods. ${ }^{27}$

Dried and freshly distilled solvents were used in the reactions.

Trichloro-(2-chlorohexyl)- $\lambda^{4}$-tellane (3). A solution of 1-hexene $(0.17 \mathrm{~g}, 2.02 \mathrm{mmol})$ in carbon tetrachloride (5 $\mathrm{mL}$ ) was added dropwise to a mixture of $0.539 \mathrm{~g}(2 \mathrm{mmol})$ of tellurium tetrachloride and carbon tetrachloride $(30 \mathrm{~mL})$. The mixture was stirred overnight at room temperature. The solvent was removed on a rotary evaporator, and the residue was dried under reduced pressure. Yield: $0.707 \mathrm{~g}$ (quantitative), light grey viscous oil. ${ }^{1} \mathrm{H}$ NMR $\left(\mathrm{CCl}_{4}, \delta\right)$, ppm: $0.99\left(\mathrm{t}, 3 \mathrm{H}, \mathrm{CH}_{3}\right), 1.35-1.67\left(\mathrm{~m}, 4 \mathrm{H}, \mathrm{C}_{2} \mathrm{H}_{4}\right), 1.87-1.99\left(\mathrm{~m}, 2 \mathrm{H}, \mathrm{CH}_{2}\right), 2.01-2.13(\mathrm{~m}, 2 \mathrm{H}$, $\left.\mathrm{CH}_{2}\right)$, 4.33-4.40 (m, $\left.1 \mathrm{H}, \mathrm{TeCH}\right)$, 4.46-4.56 (m, $\left.1 \mathrm{H}, \mathrm{TeCH}_{2}\right), 4.97-5.03(\mathrm{~m}, 1 \mathrm{H}, \mathrm{CHCl}) \mathrm{ppm} .{ }^{13} \mathrm{C} \mathrm{NMR}\left(\mathrm{CDCl}_{3}, \delta\right)$, ppm: $14.7\left(\mathrm{CH}_{3}\right), 22.6\left(\mathrm{CH}_{2}\right), 29.0\left(\mathrm{CH}_{2}\right), 38.9\left(\mathrm{CH}_{2}\right), 59.4(\mathrm{CHCl}), 68.4\left(\mathrm{TeCH}_{2}\right)$ ppm. Anal: calc. for $\mathrm{C}_{6} \mathrm{H}_{12} \mathrm{Cl}_{4} \mathrm{Te}: \mathrm{C}$, 20.38; $\mathrm{H}, 3.42 ; \mathrm{Cl}, 40.11 ; \mathrm{Te}, 36.09$; found: $\mathrm{C}, 20.65 ; \mathrm{H}, 3.23 ; \mathrm{Cl}, 39.89 ; \mathrm{Te}, 35.78 \%$.

Trichloro-(2-chloroheptyl)- $\lambda^{4}$-tellane (4). Quantitative yield, light grey viscous oil. ${ }^{1} \mathrm{H} \mathrm{NMR}\left(\mathrm{CDCl}_{3}, \delta\right), 0.98(\mathrm{t}$, $\left.3 \mathrm{H}, \mathrm{CH}_{3}\right), 1.41-1.49\left(\mathrm{~m}, 4 \mathrm{H}, \mathrm{CH}_{2}\right), 1.59-1.75\left(\mathrm{~m}, 2 \mathrm{H}, \mathrm{CH}_{2}\right), 1.95-2.09\left(\mathrm{~m}, 2 \mathrm{H}, \mathrm{CH}_{2}\right), 4.39-4.45(\mathrm{~m}, 1 \mathrm{H}, \mathrm{TeCH})$, 4.57-4.64 (m, 1H, TeCH $), 5.05-5.14(\mathrm{~m}, 1 \mathrm{H}, \mathrm{ClCH})$ ppm. $\left.{ }^{13} \mathrm{C} \mathrm{NMR}_{(\mathrm{CDCl}}, \delta\right), 13.0\left(\mathrm{CH}_{3}\right), 22.2\left(\mathrm{CH}_{2}\right), 25.1\left(\mathrm{CH}_{2}\right)$, $30.7\left(\mathrm{CH}_{2}\right), 39.0\left(\mathrm{CH}_{2}\right), 59.3(\mathrm{ClCH}), 69.2\left(\mathrm{TeCH}_{2},{ }^{1}{ }_{\mathrm{TeC}}=138 \mathrm{~Hz}\right)$. Anal: calc. for $\mathrm{C}_{7} \mathrm{H}_{14} \mathrm{Cl}_{4} \mathrm{Te}: \mathrm{C}, 22.87 ; \mathrm{H}, 3.84 ; \mathrm{Cl}$, 38.58; Te, 34.71; found: C, 22.59; $\mathrm{H}, 3.64 ; \mathrm{Cl}, 38.87$; Te, 34.97\%.

Methoxytelluration reaction. Trichloro-(2-methoxyhexyl)- $\lambda^{4}$-tellane (5). Dichloromethane $(20 \mathrm{~mL})$ was added to tellurium tetrachloride $(0.539 \mathrm{~g}, 2 \mathrm{mmol})$ and the mixture was stirred for $20 \mathrm{~min}$ at room temperature. A solution of 1-hexene $(0.2 \mathrm{~g}, 2.38 \mathrm{mmol})$ in methanol $(5 \mathrm{~mL})$ was added dropwise and the mixture was stirred overnight at room temperature. The solvent was removed on a rotary evaporator, and the residue was dried under reduced pressure. Yield: $0.698 \mathrm{~g}$ (quantitative), light grey viscous oil. ${ }^{1} \mathrm{H} N M R\left(\mathrm{CDCl}_{3}, \delta\right), \mathrm{ppm}: 0.89$ (t, $\left.3 \mathrm{H}, \mathrm{CH}_{3}\right), 1.34-1.48\left(\mathrm{~m}, 4 \mathrm{H}, \mathrm{CH}_{2}\right), 1.73-1.84\left(\mathrm{~m}, 1 \mathrm{H}, \mathrm{CH}_{2}\right), 1.95-2.04\left(\mathrm{~m}, 1 \mathrm{H}, \mathrm{CH}_{2}\right), 3.73 \mathrm{~s}\left(3 \mathrm{H}, \mathrm{OCH}_{3}\right), 4.43-4.54$ $(\mathrm{m}, 3 \mathrm{H}, \mathrm{OCH}, \mathrm{TeCH})$ ppm. ${ }^{13} \mathrm{C} \mathrm{NMR}\left(\mathrm{CDCl}_{3}, \delta\right), \mathrm{ppm}: 14.0\left(\mathrm{CH}_{3}\right), 22.6\left(\mathrm{CH}_{2}\right), 25.8\left(\mathrm{CH}_{2}\right), 33.2\left(\mathrm{CH}_{2}\right), 59.6\left(\mathrm{OCH}_{3}\right)$, $68.7\left(\mathrm{TeCH}_{2}\right), 78.3(\mathrm{OCH})$. Anal: calc. for $\mathrm{C}_{7} \mathrm{H}_{15} \mathrm{Cl}_{3} \mathrm{OTe}$ : C, 24.08; $\mathrm{H}, 4.33 ; \mathrm{Cl}, 30.46 ; \mathrm{Te}, 36.55 ;$ found: $\mathrm{C}, 23.79 ; \mathrm{H}$, 4.51; $\mathrm{Cl}, 30.17 ; \mathrm{Te}, 36.25 \%$.

Methanolysis reaction. Trichloro-(2-methoxyheptyl)- $\lambda^{4}$-tellane (6). Methanol $(6 \mathrm{ml})$ was added to a solution of tellane $4(0.735 \mathrm{~g}, 2 \mathrm{mmol})$ in dichloromethane $(25 \mathrm{~mL})$. The mixture was stirred overnight at room temperature. The solvents were removed on a rotary evaporator, and the residue was dried under reduced pressure. Yield: $0.726 \mathrm{~g}$ (quantitative), light grey viscous oil. ${ }^{1} \mathrm{H} N M R\left(\mathrm{CDCl}_{3}, \delta\right), 0.98\left(\mathrm{t}, 3 \mathrm{H}, \mathrm{CH}_{3}\right), 1.37-1.48(\mathrm{~m}$, $\left.6 \mathrm{H}, \mathrm{CH}_{2}\right), 1.72-1.82\left(\mathrm{~m}, 1 \mathrm{H}, \mathrm{CH}_{2}\right), 1.80-1.99\left(\mathrm{~m}, 1 \mathrm{H}, \mathrm{CH}_{2}\right), 3.70\left(\mathrm{~s}, 3 \mathrm{H}, \mathrm{OCH}_{3}\right), 4.34-4.41\left(\mathrm{~m}, 3 \mathrm{H}, \mathrm{TeCH}_{2}, \mathrm{OCH}\right) .{ }^{13} \mathrm{C}$ NMR $\left(\mathrm{CDCl}_{3}, \delta\right), 13.8\left(\mathrm{CH}_{3}\right), 22.2\left(\mathrm{CH}_{2}\right), 23.2\left(\mathrm{CH}_{2}\right), 31.4\left(\mathrm{CH}_{2}\right), 33.3\left(\mathrm{CH}_{2}\right), 59.1\left(\mathrm{OCH}_{3}\right), 69.4\left(\mathrm{TeCH}_{2},{ }^{1} \mathrm{JTC}_{\mathrm{TeC}} 115\right.$ $\mathrm{Hz}), 78.0(\mathrm{OCH})$. Anal: calc. for $\mathrm{C}_{8} \mathrm{H}_{17} \mathrm{Cl}_{3} \mathrm{OTe}$ : C, 26.46; $\mathrm{H}, 4.72 ; \mathrm{Cl}, 29.29 ; \mathrm{Te}, 35.13$; found: $\mathrm{C}, 26.18 ; \mathrm{H}, 4.53 ; \mathrm{Cl}$, 28.99; Te, 35.45\%.

Dichlorobis-(2-chlorohexyl)- $\lambda^{4}$-tellane (7). A solution of 1-hexene $(0.25 \mathrm{~g}, 3 \mathrm{mmol})$ in benzene $(5 \mathrm{~mL}) \mathrm{was}$ added dropwise to a mixture of tellurium tetrachloride $(0.269 \mathrm{~g}, 1 \mathrm{mmol})$ and benzene $(30 \mathrm{~mL})$. The mixture was refluxed for $10 \mathrm{~h}$. The solvent was removed on a rotary evaporator, and the residue was dried under reduced pressure. Yield: $0.437 \mathrm{~g}$ (quantitative), light grey solid, m.p. $110-111^{\circ} \mathrm{C} .{ }^{1} \mathrm{H} \mathrm{NMR}\left(\mathrm{CDCl}_{3}, \delta\right), \mathrm{ppm}: 0.97$ 
(t, 3H, $\left.\mathrm{CH}_{3}\right), 1.32-1.67\left(\mathrm{~m}, 4 \mathrm{H}, \mathrm{C}_{2} \mathrm{H}_{4}\right), 1.85-1.99\left(\mathrm{~m}, 2 \mathrm{H}, \mathrm{CH}_{2}\right), 2.03-2.13\left(\mathrm{~m}, 2 \mathrm{H}, \mathrm{CH}_{2}\right), 4.31-4.40(\mathrm{~m}, 1 \mathrm{H}, \mathrm{TeCH})$,

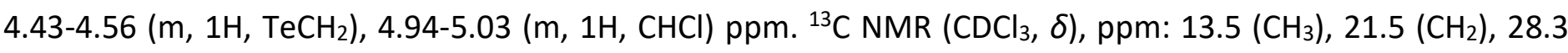
$\left(\mathrm{CH}_{2}\right), 38.2\left(\mathrm{CH}_{2}\right), 55.1,55.4\left(\mathrm{TeCH}_{2}\right), 58.0,58.1(\mathrm{CHCl})$ ppm. Anal: calc. for $\mathrm{C}_{12} \mathrm{H}_{24} \mathrm{Cl}_{4} \mathrm{Te}: \mathrm{C}, 32.93 ; \mathrm{H}, 5.53 ; \mathrm{Cl}$, 32.40; Te, 29.15; found: C, 32.65; $\mathrm{H}, 5.34 ; \mathrm{Cl}, 29.12$; Te, $28.89 \%$.

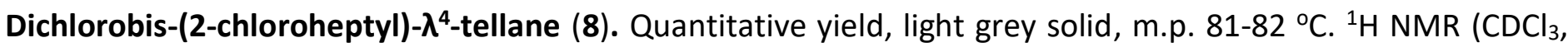
ס), $0.98\left(\mathrm{t}, 3 \mathrm{H}, \mathrm{CH}_{3}\right), 1.38-1.44\left(\mathrm{~m}, 4 \mathrm{H}, \mathrm{CH}_{2}\right), 1.53-1.70\left(\mathrm{~m}, 2 \mathrm{H}, \mathrm{CH}_{2}\right), 1.90-2.00\left(\mathrm{~m}, 2 \mathrm{H}, \mathrm{CH}_{2}\right), 3.86-3.97(\mathrm{~m}, 1 \mathrm{H}$, $\left.\mathrm{TeCH}_{2}\right)$, 4.04-4.11 (m, 1H, TeCH $\left.\left.\mathrm{T}_{2}\right), 4.76-4.84(\mathrm{~m}, 1 \mathrm{H}, \mathrm{ClCH}) \mathrm{ppm} .{ }^{13} \mathrm{C} \mathrm{NMR}_{(\mathrm{CDCl}}, \delta\right), 14.1\left(\mathrm{CH}_{3}\right), 22.5\left(\mathrm{CH}_{2}\right), 26.4$ $\left(\mathrm{CH}_{2}\right), 31.1\left(\mathrm{CH}_{2}\right), 39.1\left(\mathrm{CH}_{2}\right), 56.0,56.2\left(\mathrm{TeCH}_{2}\right), 58.3,58.4(\mathrm{ClCH})$. Elemental analysis for $\mathrm{C}_{14} \mathrm{H}_{28} \mathrm{Cl}_{4} \mathrm{Te}(\%)$ : found: $35.95(\mathrm{C}) ; 5.89(\mathrm{H}) ; 30.75(\mathrm{Cl}) ; 27.69$ (Te); calculated: $36.10(\mathrm{C}) ; 6.06(\mathrm{H}) ; 30.45$ (Cl); 27.39 (Te). Anal: calc. for $\mathrm{C}_{14} \mathrm{H}_{28} \mathrm{Cl}_{4}$ Te: $\mathrm{C}, 36.10 ; \mathrm{H}, 6.06 ; \mathrm{Cl}, 30.45 ; \mathrm{Te}, 27.39$; found: $\mathrm{C}, 35.95 ; \mathrm{H}, 5.89 ; \mathrm{Cl}, 30.75 ; \mathrm{Te}, 27.69 \%$.

Ethoxytelluration reaction. Trichloro-(2-ethoxyhexyl)- $\lambda$-tellane (9). Dichloromethane $(20 \mathrm{~mL})$ was added to tellurium tetrachloride $(0.539 \mathrm{~g}, 2 \mathrm{mmol})$ and the mixture was stirred for $20 \mathrm{~min}$ at room temperature. A solution of 1-hexene $(0.2 \mathrm{~g}, 2.38 \mathrm{mmol})$ in ethanol $(5 \mathrm{~mL})$ was added dropwise and the mixture was stirred at room temperature for $2 \mathrm{~h}$ and at reflux for $6 \mathrm{~h}$. The solvent was removed on a rotary evaporator, and the residue was dried under reduced pressure. Yield: $0.726 \mathrm{~g}$ (quantitative), light grey viscous oil. ${ }^{1} \mathrm{H} \mathrm{NMR}\left(\mathrm{CDCl}{ }_{3}\right.$, $\delta), 0.98\left(\mathrm{t}, 3 \mathrm{H}, \mathrm{CH}_{3}\right), 1.32-1.49\left(\mathrm{~m}, 7 \mathrm{H}, \mathrm{CH}_{2}, \mathrm{CH}_{3}\right), 1.74-1.85\left(\mathrm{~m}, 1 \mathrm{H}, \mathrm{CH}_{2}\right), 1.92-2.02\left(\mathrm{~m}, 1 \mathrm{H}, \mathrm{CH}_{2}\right), 3.83-3.92(\mathrm{~m}$,

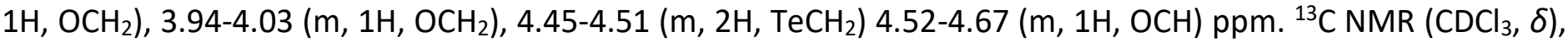
$14.0\left(\mathrm{CH}_{3}\right), 14.6\left(\mathrm{CH}_{3}\right), 22.6\left(\mathrm{CH}_{2}\right), 26.0\left(\mathrm{CH}_{2}\right), 33.8\left(\mathrm{CH}_{2}\right), 68.1\left(\mathrm{OCH}_{2}\right), 68.6\left(\mathrm{TeCH}_{2}\right), 76.8(\mathrm{OCH})$. Anal: calc. for $\mathrm{C}_{8} \mathrm{H}_{17} \mathrm{Cl}_{3} \mathrm{OTe}$ : C, 26.46; $\mathrm{H}, 4.72 ; \mathrm{Cl}, 29.29 ; \mathrm{Te}, 35.13$; found: $\mathrm{C}, 26.73 ; \mathrm{H}, 4.89 ; \mathrm{Cl}, 29.57 ; \mathrm{Te}, 34.80 \%$.

Ethanolysis reaction. Trichloro-(2-ethoxyheptyl)- $\lambda^{4}$-tellane $(10)$. Ethanol $(8 \mathrm{ml})$ was added to a solution of tellane $4(0.735 \mathrm{~g}, 2 \mathrm{mmol})$ in dichloromethane $(25 \mathrm{~mL})$. The mixture was stirred at room temperature for $1 \mathrm{~h}$ and at reflux for $6 \mathrm{~h}$. The solvents were removed on a rotary evaporator, and the residue was dried under reduced pressure. Yield: $0.754 \mathrm{~g}$ (quantitative), light grey viscous oil. ${ }^{1} \mathrm{H} \mathrm{NMR}\left(\mathrm{CDCl}_{3}, \delta\right), 0.98\left(\mathrm{t}, 3 \mathrm{H}, \mathrm{CH}_{3}\right), 1.35$ $1.50\left(\mathrm{~m}, 9 \mathrm{H}, \mathrm{CH}_{2}, \mathrm{CH}_{3}\right), 1.77-1.87\left(\mathrm{~m}, 1 \mathrm{H}, \mathrm{CH}_{2}\right), 1.95-2.05\left(\mathrm{~m}, 1 \mathrm{H}, \mathrm{CH}_{2}\right), 3.87-3.95\left(\mathrm{~m}, 1 \mathrm{H}, \mathrm{OCH}_{2}\right), 3.96-4.06(\mathrm{~m}$, $\left.1 \mathrm{H}, \mathrm{OCH}_{2}\right), 4.47-4.53\left(\mathrm{~m}, 2 \mathrm{H}, \mathrm{Cl}_{3} \mathrm{TeCH}_{2}\right), 4.55-4.65(\mathrm{~m}, 1 \mathrm{H}, \mathrm{OCH}) \mathrm{ppm} .{ }^{13} \mathrm{C} \mathrm{NMR}\left(\mathrm{CDCl}_{3}, \delta\right), 13.9\left(\mathrm{CH}_{3}\right), 14.6$ $\left(\mathrm{CH}_{3}\right), 22.4\left(\mathrm{CH}_{2}\right), 23.6\left(\mathrm{CH}_{2}\right), 31.6\left(\mathrm{CH}_{2}\right), 34.0\left(\mathrm{CH}_{2}\right), 68.1\left(\mathrm{OCH}_{2}\right), 68.7\left(\mathrm{TeCH}_{2}\right), 76.8(\mathrm{OCH})$. Anal: calc. for $\mathrm{C}_{9} \mathrm{H}_{19} \mathrm{Cl}_{3} \mathrm{OTe}$ : C, 28.66; $\mathrm{H}, 5.08 ; \mathrm{Cl}, 28.20 ; \mathrm{Te}, 33.83$; found: $\mathrm{C}, 28.38 ; \mathrm{H}, 4.89 ; \mathrm{Cl}, 27.91 ; \mathrm{Te}, 33.52 \%$.

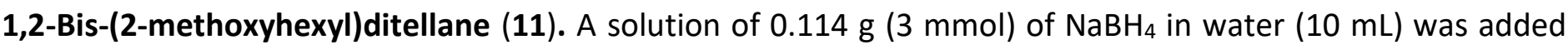
dropwise for $30 \mathrm{~min}$ to a solution of tellane $5(0.698 \mathrm{~g}, 2 \mathrm{mmol})$ in THF $(20 \mathrm{~mL})$ cooled to $-20{ }^{\circ} \mathrm{C}$. The reaction mixture was stirred at $-20^{\circ} \mathrm{C}$ for $2 \mathrm{~h}$ and allowed to warm to room temperature with stirring. The organic solvent was removed on a rotary evaporator, the residue was extracted with $\mathrm{CCl}_{4}$. The extract was dried with $\mathrm{CaCl}_{2}$, the solvent was removed on a rotary evaporator and the residue was dried in vacuum. Yield $0.466 \mathrm{~g}$ (96\%), dark-red oil. ${ }^{1} \mathrm{H} \mathrm{NMR}\left(\mathrm{CDCl}_{3}, \delta\right), 0.95\left(\mathrm{t}, 6 \mathrm{H}, \mathrm{CH}_{3}\right), 1.29-1.46\left(\mathrm{~m}, 12 \mathrm{H}, \mathrm{C}_{4} \mathrm{H}_{8}\right), 1.51-1.68 \mathrm{~m}\left(4 \mathrm{H}, \mathrm{CH}_{2}\right), 3.12-$ $3.19(\mathrm{~m}, 2 \mathrm{H}, \mathrm{OCH}), 3.36\left(\mathrm{~s}, 6 \mathrm{H}, \mathrm{OCH}_{3}\right), 3.38-3.46\left(\mathrm{~m}\left(4 \mathrm{H}, \mathrm{TeCH}_{2}\right) .{ }^{13} \mathrm{C} \mathrm{NMR}_{(\mathrm{CDCl}}, \delta\right), 12.4\left(\mathrm{TeCH}_{2}\right), 14.3\left(\mathrm{CH}_{3}\right)$, $22.8\left(\mathrm{CH}_{2}\right), 29.6\left(\mathrm{CH}_{2}\right), 32.0\left(\mathrm{CH}_{2}\right), 56.4\left(\mathrm{OCH}_{3}\right), 81.1(\mathrm{OCH})$. Anal: calc. for $\mathrm{C}_{14} \mathrm{H}_{30} \mathrm{O}_{2} \mathrm{Te}_{2}: \mathrm{C}, 34.63 ; \mathrm{H}, 6.23 ; \mathrm{Te}$, 52.55; found: C, 34.48; $\mathrm{H}, 6.38 ; \mathrm{Te}, 52.29 \%$.

1,2-Bis-(2-methoxyheptyl)ditellane (12). Yield: 98\%, dark-red oil. ${ }^{1} \mathrm{H} \mathrm{NMR}\left(\mathrm{CDCl}_{3}, \delta\right), 0.97\left(\mathrm{t}, 6 \mathrm{H}, \mathrm{CH}_{3}\right), 1.24$ $1.44\left(\mathrm{~m}, 12 \mathrm{H}, \mathrm{C}_{4} \mathrm{H}_{8}\right), 1.55-1.68 \mathrm{~m}\left(6 \mathrm{H}, \mathrm{CH}_{2}\right), 3.09-3.19(\mathrm{~m}, 2 \mathrm{H}, \mathrm{OCH}), 3.36\left(\mathrm{~s}, 6 \mathrm{H}, \mathrm{OCH}_{3}\right), 3.38-3.46(\mathrm{~m}(4 \mathrm{H}$, $\left.\mathrm{TeCH}_{2}\right) .{ }^{13} \mathrm{C} \mathrm{NMR}\left(\mathrm{CDCl}_{3}, \delta\right), 12.7\left(\mathrm{TeCH}_{2}\right), 14.1\left(\mathrm{CH}_{3}\right), 22.9\left(\mathrm{CH}_{2}\right), 26.2\left(\mathrm{CH}_{2}\right), 29.3\left(\mathrm{CH}_{2}\right), 31.9\left(\mathrm{CH}_{2}\right), 56.5\left(\mathrm{OCH}_{3}\right)$, $81.1(\mathrm{OCH})$. Anal: calc. for $\mathrm{C}_{16} \mathrm{H}_{34} \mathrm{O}_{2} \mathrm{Te}_{2}$ : $\mathrm{C}, 37.41 ; \mathrm{H}, 6.67 ; \mathrm{Te}, 49.68 ;$ found: $\mathrm{C}, 37.25 ; \mathrm{H}, ; 6.86 ; \mathrm{Te}, 49.38 \%$.

1,2-Bis-(2-ethoxyhexyl)ditellane (13). Yield: 97\%, dark-red oil. ${ }^{1} \mathrm{H} \mathrm{NMR}\left(\mathrm{CDCl}_{3}, \delta\right), 0.98\left(\mathrm{t}, 3 \mathrm{H}, \mathrm{CH}_{3}\right), 1.32-1.49$ $\left(\mathrm{m}, 7 \mathrm{H}, \mathrm{CH}_{2}, \mathrm{CH}_{3}\right), 1.74-1.85\left(\mathrm{~m}, 1 \mathrm{H}, \mathrm{CH}_{2}\right), 1.92-2.02\left(\mathrm{~m}, 1 \mathrm{H}, \mathrm{CH}_{2}\right), 3.83-3.92\left(\mathrm{~m}, 1 \mathrm{H}, \mathrm{OCH}_{2}\right), 3.94-4.03(\mathrm{~m}, 1 \mathrm{H}$, $\left.\mathrm{OCH}_{2}\right), 4.45-4.51\left(\mathrm{~m}, 2 \mathrm{H}, \mathrm{TeCH}_{2}\right), 4.52-4.67(\mathrm{~m}, 1 \mathrm{H}, \mathrm{OCH}) \mathrm{ppm} .{ }^{13} \mathrm{C} \mathrm{NMR}_{\left(\mathrm{CDCl}_{3}, \delta\right),} 13.44\left(\mathrm{TeCH}_{2}\right), 14.74\left(\mathrm{CH}_{3}\right)$, 
$16.20\left(\mathrm{CH}_{3}\right), 23.35\left(\mathrm{CH}_{2}\right), 28.16\left(\mathrm{CH}_{2}\right), 35.17\left(\mathrm{CH}_{2}\right), 64.63\left(\mathrm{OCH}_{2}\right), 80.91(\mathrm{OCH})$. Anal: calc. for $\mathrm{C}_{16} \mathrm{H}_{34} \mathrm{O}_{2} \mathrm{Te}_{2}: \mathrm{C}_{\text {, }}$ 37.41; $\mathrm{H}, 6.67$; Te, 49.68; found: C, 37.69; H, 6.86; Te, 49.35\%.

1,2-Bis-(2-ethoxyheptyl)ditellane (14). Yield: 95\%, dark-red oil. ${ }^{1} \mathrm{H} \mathrm{NMR}\left(\mathrm{CDCl}_{3}, \delta\right), 1.03\left(\mathrm{t}, 3 \mathrm{H}, \mathrm{CH}_{3}\right), 1.30(\mathrm{t}$, $\left.3 \mathrm{H}, \mathrm{CH}_{3}\right), 1.36-1.53\left(\mathrm{~m}, 6 \mathrm{H}, \mathrm{CH}_{2}\right), 1.61-1.70\left(\mathrm{~m}, 2 \mathrm{H}, \mathrm{CH}_{2}\right), 3.32-3.40\left(\mathrm{~m}, 1 \mathrm{H}, \mathrm{TeCH}_{2}\right), 3.43-3.59(\mathrm{~m}, 3 \mathrm{H}, \mathrm{TeCH}$, $\left.\mathrm{OCH}_{2}\right)$ 3.60-3.69 (m, 1H, OCH) ppm. ${ }^{13} \mathrm{C} \mathrm{NMR}\left(\mathrm{CDCl}_{3}, \delta\right), 13.5\left(\mathrm{TeCH}_{2}\right), 14.7\left(\mathrm{CH}_{3}\right), 16.2\left(\mathrm{CH}_{3}\right), 23.2\left(\mathrm{CH}_{2}\right), 25.6$ $\left(\mathrm{CH}_{2}\right), 32.6\left(\mathrm{CH}_{2}\right), 35.4\left(\mathrm{CH}_{2}\right), 64.6\left(\mathrm{OCH}_{2}\right), 80.9(\mathrm{OCH})$. Anal: calc. for $\mathrm{C}_{18} \mathrm{H}_{38} \mathrm{O}_{2} \mathrm{Te}_{2}: \mathrm{C}, 39.91 ; \mathrm{H}, 7.07 ; \mathrm{Te}, 47.11$; found: $\mathrm{C}, 40.20 ; \mathrm{H}, 6.89 ; \mathrm{Te}, 46.78 \%$.

\section{Acknowledgements}

The authors would like to thank the Baikal Analytical Center for joint use of Siberian Branch of Russian Academy of Sciences for NMR and analytical studies.

\section{References}

1. Petragnani, N.; Stefani, H. A. Tetrahedron 2005, 61, 1613. https://doi.org/10.1016/j.tet.2004.11.076

2. Zeni G., Ludtke D. S., Panatieri R. B., Braga A. L. Chem. Rev. 2006, 106, 1032. https://doi.org/10.1021/cr0505730

3. Cunha, R. L.O.R.; Gouvea, I. E.; Juliano, L. Ann. Braz. Acad. Sci. 2009, 81, 393. http://dx.doi.org/10.1590/S0001-37652009000300006

4. Detty, M. R. In Patai's Chemistry of Functional Groups. Organic Selenium and Tellurium Compounds; Rappoport, Z., Ed.; John Wiley and Sons: Chichester, 2011.

https://doi.org/10.1002/9780470682531.pat0574

5. Tiekink, E. R. T. Dalton Trans. 2012, 41, 6390. https://doi.org/10.1039/C2DT12225A

6. Halpert, G.; Sredni, B. Autoimmun. Rev. 2014, 13, 1230. https://doi.org/10.1016/i.autrev.2014.08.003

7. Ba, L. A.; Döring, M.; Jamier, V.; Jacob, C. Org. Biomol. Chem. 2010, 8, 4203. https://doi.org/10.1039/c00b00086h

8. Nogueira, C. W.; Zeni, G.; Rocha, J. B. T. Chem. Rev. 2004, 104, 6255. https://doi.org/10.1021/cr0406559

9. Mugesh, G.; du Mont, W. W.; Sies, H. Chem. Rev. 2001, 101, 2125. https://doi.org/10.1021/cr000426w

10. De Moura Campos, M.; Petragnani, N. Tetrahedron 1962, 18, 521. https://doi.org/10.1016/S0040-4020(01)92701-2

11. Arpe, H. J.; Kuckertz, H. Angew. Chem. 1971, 10, 73. https://doi.org/10.1002/anie.197100731

12. Kobelt, D.; Paulus, E. F. J. Organometal. Chem. 1971, 27, C63. https://doi.org/10.1016/S0022-328X(00)82158-0

13. Ogawa, M.; Ishioka, R. Bull. Chem. Soc. Jpn. 1970, 43, 496. https://doi.org/10.1246/bcsj.43.496 
14. Bäckvall, J. E.; Engman, L. Tetrahedron Lett. 1981, 22, 1919. https://doi.org/10.1016/S0040-4039(01)90478-2

15. Bäckvall, J. E.; Bergman, J.; Engman L. J. Org. Chem. 1983, 48, 3918. https://doi.org/10.1021/jo00170a009

16. Musalova, M. V.; Potapov, V. A.; Amosova, S. V. Molecules 2012, 17, 5770. https://doi.org/10.3390/molecules17055770

17. Potapov, V. A.; Musalova, M. V.; Musalov, M. V.; Amosova, S. V. Russ. J. Org. Chem. 2013, 49, 1703. https://doi.org/10.1134/S1070428013110237

18. Musalova, M. V.; Musalov, M. V.; Potapov, V. A.; Amosova, S. V. Russ. J. Org. Chem. 2017, $53,299$. https://doi.org/10.1134/S1070428017020270

19. Udalova, S. I.; Musalova, M. V.; Musalov, M. V.; Potapov, V. A.; Amosova, S. V. Russ. J. Org. Chem. 2017, 53, 652. https://doi.org/10.1134/S1070428017050025

20. Musalova, M. V.; Udalova, S. I.; Musalov, M. V.; Potapov, V. A.; Amosova, S. V. Russ. J. Org. Chem. 2016, $52,1509$. https://doi.org/10.1134/S1070428016100225

21. Potapov, V. A.; Musalov, M. V.; Musalova, M. V.; Amosova, S. V. Russ. Chem. Bull. 2009, $58,2404$. https://doi.org/10.1007/s11172-009-0335-5

22. Musalova, M. V.; Musalov, M. V.; Potapov, V. A.; Amosova, S. V. Russ. Chem. Bull. 2012, 61, 2363. https://doi.org/10.1007/s11172-012-0333-x

23. Potapov, V. A.; Khabibulina, A. G.; Musalova, M. V.; Chernyshev, K. A.; Amosova, S. V. Russ. J. Org. Chem. 2014, 50, 150.

https://doi.org/10.1134/S1070428014010308

24. Musalova, M. V.; Musalov, M. V.; Potapov, V. A.; Chernyshev, K. A.; Amosova, S. V. Russ. Chem. Bull. 2012, 61, 2365.

https://doi.org/10.1007/s11172-012-0334-9

25. Musalova, M. V.; Musalov, M. V.; Potapov, V. A.; Amosova, S. V. Russ. J. Org. Chem. 2017, $53,301$. https://doi.org/10.1134/S1070428017020282

26. Chieffi, A.; Menezes, P. H.; Comasseto, J. V. Organometallics 1997, 16, 809. https://doi.org/10.1021/om960409q

27. Gelman, N. E.; Terent'eva, E. A.; Shanina, T. M.; Kiparenko, L. M. Metody kolichestvennogo organicheskogo elementnogo analiza (Methods of quantitative organic element analysis); Khimiya: Moscow, 1987; p. 106 (in Russian). 